\title{
Invasive arterial blood pressure in the neonatal intensive care: a valuable tool to manage very ill preterm and term neonates
}

\author{
Michelina Di Biase*, Anna Casani, Luigi Orfeo \\ From XXI Congress of the Italian Society of Neonatology \\ Palermo, Italy. 24-26 September 2015
}

Blood pressure monitoring is essential in managing hemodynamically unstable neonates and preterm infants. Non-invasive blood pressure measurement (NIBP) with oscillometric technique is in widespread use in the Neonatal Intensive Care Units (NICUs). Nonetheless NIBP is not pretty accurate when compared with invasive monitoring since it generally over read mean blood pressure in particular when the infants are hypotensive so it falsely reassures neonatologists [1-4]. Invasive arterial blood pressure (IABP) methods is considered the gold standard for circulatory management of ill neonates [5]. Along with the more accuracy, IABP measurement has a number of advantages over NIBP, namely it allows beat-to-beat pressure measurement to closely monitor patients with very changeable conditions, arterial blood sampling is easily performed as well as cardiac stroke volume can be derived from characteristics of the arterial pressure pulse. The commonly used method is by means of an umbelical artery catheter, wherever possible, or by placing a cannula needle in a different artery, usually radial [5-8]; a column fluid directly connects the arterial system to a pressure transducer where the arterial pulse is converted into an electrical signal that in turn will be processed via a microprocessor, amplified and eventually displayed as the blood pressure waveform against time [5]. In order to ensure a reliable assessment of blood pressure nurses should be wary about one of the commonest sources of error, namely introduction of small air bubble in the system [5]. Thrombo-embolism, vasospasm, thrombosis, haemorrage and infection are complications of arterial cannulation [9]. Haematoma and peripheral nerve injury may

* Correspondence: michela-db@libero.it

Neonatal Intensive Care Unit, Maternal and Child Health Department, Rummo Hospital Benevento, Italy original work is properly cited. The Creative Commons Public Domain Dedication waiver (http://creativecommons.org/publicdomain/ zero/1.0/) applies to the data made available in this article, unless otherwise stated. 
8. Schindler E, Kowald B, Suess H, Niehaus-Borquez B, Tausch B, Brecher A: Catheterization of the radial or brachial artery in neonates and infants. Paediatr Anaesth 2005, 15:677-678.

9. Furdon SA, Horgan MJ, Bradshaw WT, Clark DA: Nurse's guide to early detection of umbelical arterial catheter complications in infant. Adv Neonatal Care 2006, 6:246-256.

10. Nugent J: Intra-arterial blood pressure monitoring in the neonate. JOGN Nurs 1982, 11:281-287.

11. Norforlk, Suffolk \& Cambridgeshire Neonatal Network: Clinical Guideline: Peripheral Arterial Cannulation. 2007 [http://www.neonatal.org.uk/ documents/3270.pdf], Downloaded 22/03/2013.

12. Hack WW, Vos A, Okken A: Incidence of forearm and hand ischaemia related to radial artery cannulation in newborn infants. Intensive Care Med 1990, 16:50-53.

13. MacDonald MG: Peripheral Artery Cannulation Chb29. In Atlas of Procedures in Neonatology.. 3rd Ed edition. Lippincott Williams \& Wilkins, Philadelphia;MacDonald, M.G. \& Ramasethu, J 2002:

14. Kaleidoscope The Children's Health Network: Peripheral Arterial Line in NICU - Insertion, Care and Removal of Guideline / Procedure., Accessed 26/03/2013 http://www.kaleidoscope.org.au/docs/gl/pal_nicu.pdf.

15. Newborn Services Clinical Guide: Intravascular Catheters peripheral Arterial Lines. 2006, Accessed on 22/03/2013 http://www.adhb.govt.nz.

doi:10.1186/1824-7288-41-S1-A9

Cite this article as: Di Biase et al:: Invasive arterial blood pressure in the neonatal intensive care: a valuable tool to manage very ill preterm and term neonates. Italian Journal of Pediatrics 2015 41(Suppl 1):A9.

\section{Submit your next manuscript to BioMed Central and take full advantage of:}

- Convenient online submission

- Thorough peer review

- No space constraints or color figure charges

- Immediate publication on acceptance

- Inclusion in PubMed, CAS, Scopus and Google Scholar

- Research which is freely available for redistribution

Submit your manuscript at www.biomedcentral.com/submit 